Mycologia, 98(1), 2006, pp. 23-30.

(C) 2006 by The Mycological Society of America, Lawrence, KS 66044-8897

\title{
Characterization and identification of field ectomycorrhizae of Boletus edulis and Cistus ladanifer
}

Beatriz Águeda ${ }^{1}$

Departamento de Investigación y Experiencias Forestales de Valonsadero, Consejería de Medio Ambiente, Junta de Castilla y León, Apdo. de correos 175, E-42080 Soria, España

Javier Parladé

IRTA, Departament de Protecció Vegetal, Ctra. Cabrils s/n, E-08348 Cabrils (Barcelona), España

Ana María de Miguel

Universidad de Navarra, Facultad de Ciencias, Departamento de Botánica, E-31008 Pamplona, España

Fernando Martínez-Peña

Departamento de Investigación y Experiencias Forestales de Valonsadero, Consejería de Medio Ambiente, Junta de Castilla y León, Apdo. de correos 175, E-42080 Soria, España

Abstract: Field ectomycorrhizae sampled under Boletus edulis and Cistus ladanifer have been characterized and described in detail based on standard morphological and anatomical characters. The described ectomycorrhiza has traits typical of Boletales: whitish with three differentiated plectenchymatous layers in the mantle in plan view forming ring-like structures and rhizomorphs with highly differentiated hyphae. The inflated, smooth cystidia-like clavate end cells on the surface of the rhizomorphs and their slightly twisted external hyphae are additional characterizing features. The Hartig net occupies $1 \frac{1}{2}$ rows of cortical cells, partly reaching the endodermis. Not all hyphae have clamps. The identification of the fungal symbiont as B. edulis was confirmed by ITS rDNA sequence comparison between mycorrhizas and sporocarps. The singularity of this symbiotic association, as well as its ecological and practical implications, are discussed.

Key words: anatomy, description, ITS rDNA, morphology

\section{INTRODUCTION}

Boletus L., especially the Boletus edulis species complex, is a cosmopolitan genus of ectomycorrhizal fungi widely represented in the warmer parts of the Northern Hemisphere. These species have a great

Accepted for publication 11 Nov 2005.

${ }^{1}$ Correponding author. E-mail: aguherbe@jcyl.es economic importance for their edibility (Singer 1986, Hall et al 1998). The genus comprises more than 1000 species with epigeous fructification, inhabiting forests in tropical and midlatitudes, forming ectomycorrhizae mainly with trees and shrubs of Pinaceae, Fagaceae and Betulaceae (Singer 1986).

The B. edulis species complex includes four species: B. aereus Bull., B. aestivalis (Paulet) Fr., B. edulis Bull. and B. pinophilus Pilát \& Dermek. The identification of the fruiting bodies of these four species traditionally has been difficult because it is based exclusively on a few, highly variable morphological characters. Recent studies showed that these four species can be successfully discriminated by an extensive analysis of the internal transcribed spacer of the nuclear rDNA region (Leonardi et al 2005).

The plants of the Cistaceae family are fairly abundant in the Northern Hemisphere and South America. The family has eight genera with almost 200 species (Muñoz and Navarro 1993). The Cistus genus is represented in the Iberian Peninsula by 12 shrub species, all belonging to primary succession stages of tree stands, growing readily in degraded areas. The Cistaceae species in general are pyrophytic. Their germination is related to high temperatures, and they are adapted to fires in Mediterranean forests (Alonso et al 1992). Cistus ladanifer L. lives in the western Mediterranean, from Portugal and Morocco to the French Riviera and Algeria, in zones with hot, dry summers, $0-1500 \mathrm{~m}$ a.s.l., on silicon soil in the southern half of the Iberian Peninsula and on slate and granite in the western part (Demoly and Monserrat 1993).

All Cistaceae are ectomycorrhizal plants (Brundrett 2002, Smith and Read 1997), but available descriptions for Cistus ectomycorrhizal types are scarce. Only four morphotypes of ectomycorrhizae described in association with Cistus sp. have been found; they are B. rhodoxanthus (Krombh.) Kallenb. with Cistus cf. ladanifer (Hanh 2001), Laccaria laccata (Scop.) Fr. with C. ladanifer (Torres et al 1995), Lactarius tesquorum Malençon with Cistus sp. (Nuytinck et al 2004) and Tuber nigrum Allioni with C. incanus L. (Fontana and Giovanetti 1978-1979, Fusconi 1983, Wenkart et al 2001). Rockroses (Cistus and Helianthemum) are ecologically important species because they may act as a reservoir of mycorrhizal fungi inoculum after a forest disturbance (Torres et al 1995, Díez 1998). 
TABLE I. Literature references of harvesting of Boletales carpophores in stands with Cistaceae species in Spain

\begin{tabular}{|c|c|c|}
\hline Species & Host & Reference \\
\hline $\begin{array}{l}\text { Boletus aemilii } \text { Barbier } \\
\text { Boletus aereus } \text { Bull. } \\
\text { Bolatus aestivalis (Paulet) Fr. } \\
\text { Boletus corsicus } \text { Rolland } \\
\text { Boletus impolitus } \text { Fr. } \\
\text { Boletus queletii Schulz. var. zugazae Moreno } \\
\text { Boletus rhodoxanthus Kallenb. } \\
\text { Chalciporus piperatus (Bull. ex Fr.) Bataille. } \\
\text { Leccinum corsicum (Roll.) Sing. }\end{array}$ & $\begin{array}{l}\text { Cistus sp. } \\
\text { Cistus sp. } \\
\text { Cistus sp. } \\
\text { Cistus ladanifer } \mathrm{L} . \\
\text { Cistus monspeliensis } \mathrm{L} . \\
\text { Cistus ladanifer } \mathrm{L} . \\
\text { Cistus cf. ladanifer } \mathrm{L} . \\
\text { Cistus ladanifer L. } \\
\text { Cistus sp. } \\
\text { Cistus sp. } \\
\text { Cistus albidus } \mathrm{L} . \\
\text { Cistus ladanifer } \mathrm{L} . \\
\text { Cistus laurifolius } \mathrm{L} . \\
\text { Cistus monspeliensis } \mathrm{L} . \\
\text { Cistus ladanifer } \mathrm{L} . \\
\text { Cistus ladanifer L. } \\
\text { Cistus sp. } \\
\text { Cistus populifolius } \mathrm{L} . \\
\text { Cistus sp. } \\
\text { Cistus ladanifer L. }\end{array}$ & $\begin{array}{l}\text { Llamas and Terrón } 2003 \\
\text { Sánchez Rodríguez et al. } 2004 \\
\text { Sánchez Rodríguez et al. } 2004 \\
\text { Oria de Rueda and Díez } 2002 \\
\text { Pando } 2000 \\
\text { Moreno } 1977 \\
\text { Hahn } 2001 \\
\text { Pando } 2000 \\
\text { Llamas and Terrón } 2003 \\
\text { Sánchez Rodríguez et al. } 2004 \\
\text { Moreno Arroyo et al. } 1996 \\
\text { Moreno Arroyo et al. } 1996 \\
\text { Pando } 2000 \\
\text { Oria de Rueda and Díez } 2002 \\
\text { Moreno Arroyo et al. } 1996 \\
\text { Moreno } 1977 \\
\text { Pando } 2000 \\
\text { Pando } 2000 \\
\text { Pando } 2000 \\
\text { Pando } 2000 \\
\text { Pando } 2000\end{array}$ \\
\hline
\end{tabular}

Previous references to Cistaceae associations with Boletales in Spain have been compiled (TABLE I). No previous worldwide literature references have been found about the harvest of Boletus edulis sporocarps in pure stands of Cistus sp. The aim of this paper is to provide a first description and characterization of the ectomycorrhizae of B. edulis on C. ladanifer collected in their natural habitat, as well as the molecular analyses of the fungal symbiont.

\section{MATERIAL AND METHODS}

The Boletus edulis sporocarps and ectomycorrhizae were collected in Nov 2004 in a single area of the province of Zamora, in the municipality of Riofrío (Castilla y León, España), UTM co-ord.: 29T0 735590, 4633695, about $872 \mathrm{~m}$ a.s.l., in loamy soil composed of slate and sandstone, $\mathrm{pH}$ 5.0. The harvested fungal specimens were collected in pure stands of 8 y old Cistus ladanifer shrubs. No trees were present. Soil cores were collected from beneath the sporocarps and stored at $4 \mathrm{C}$ for analysis in the laboratory. The roots with ectomycorrhizae and the soil rhizomorphs were extracted carefully with the aid of a stereomicroscope. The use of water was avoided because of the clay soil. To complete the cleaning, the excised roots and ectomycorrhizae were placed in an ultrasonic bath with deionized water and some drops of Tween $20^{\circledR}$ detergent at $20 \mathrm{C}$ for $15 \mathrm{~min}$. Samples of the sporocarps, ectomycorrhizae and rhizomorphs were frozen immediately at $-20 \mathrm{C}$ for further molecular analyses. Dried sporocarps and ectomycorrhizae fixed in FAA (Verlhac et al 1990) were stored as voucher specimens in the Dpto. Inv. Exp. For. Valonsadero with the codes: VALONSADERO-FUNGI 2081 and VALONSADERO-MYCORRHIZA 019 respectively.

The general methodology and terminology for characterizing the ectomycorrhizae follows Agerer (1987-2002, 1991) and Agerer and Rambold (2004-2005). For observation of the mantle ectomycorrhizae were grated with the peeling technique (Agerer 1991). Mantle and rhizomorph preparations of fresh ectomycorrhizae were fixed on slides with lacto-glycerine for microscope observation. For longitudinal and cross sections (5-7 $\mu \mathrm{m}$ thick) ectomycorrhizae and rhizomorphs were embedded in liquid parafine, cut with a Microm HM 340E microtome and stained with hematoxilin-eosin.

Molecular characterization was carried out by sequencing fragments of the nuclear ribosomal DNA region of sporocarps, ectomycorrhizae and rhizomorphs. DNA extraction from fungal tissue, ectomycorrhizae and rhizomorphs was performed with the QIAGEN ${ }^{\circledR}$ DNeasy Plant Mini Kit. Amplifications of ITS rDNA sequences were carried out with an Applied Biosystems ${ }^{\circledR} 9700$ PCR machine using the universal primers ITS1 (5'-TCCGTAGGTGAACCTGCGG-3') and ITS4 (5'-TCCTCCGCTTATTGATATGC-3') (White et al 1990) as well as the fungal specific ITS1F (5'-CTTGGTCATTTAGAGGAAGTAA-3') (Gardes and Bruns 1993) and the Boletus specific BED-4 (5'GTTTGTATACATTCTGGACATGCG-3') (Moor et al 2002). Sequence alignments were performed with the BioEdit program version 5.0.9 (Hall 1999). Identification was carried out by comparing our sequences with the existing ones in the GenBank database. 

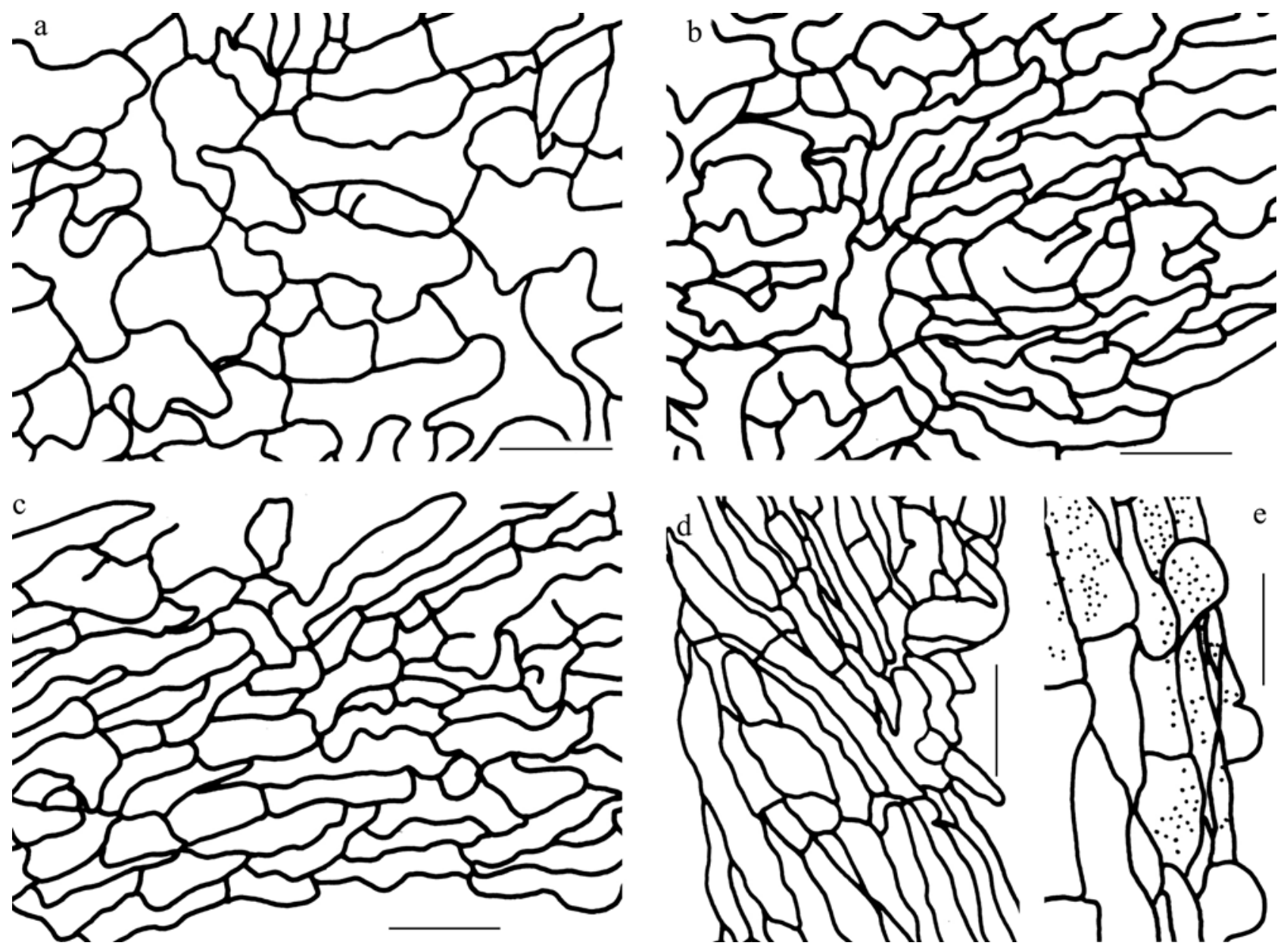

FIG. 1. Anatomical characters of B. edulis ectomycorrhizae. (a) Outer mantle layer with a plectenchymatous structure formed by a loose net of hyphae. (b) Middle mantle layer with a plectenchymatous structure forming ring-like structures. (c) Inner mantle layer with a densely plectenchymatous structure. (d) Surface of rhizomorph, showing slightly twisted hyphae. (e) Vesicles on the margin of rhizomorph. Bars $=10 \mu \mathrm{m}$.

\section{RESULTS}

Morphological characters.-Ectomycorrhizal system infrequently found, $1.5-1.8 \mathrm{~mm}$ long, monopodial-pinnate, ramifications of second order lacking or less developed, with four tips per $10 \mathrm{~mm}$ (FIG. 2a). Main axes $0.2-0.3 \mathrm{~mm}$ diam. Unramified ends $0.4-0.6 \mathrm{~mm}$ long, $0.2-0.3 \mathrm{~mm}$ diam, sinuous, yellow whitish getting more yellow with age, whitish tip, not contrasting, inflated, clubshaped. Surface of unramified ends smooth and shiny, distinct, mantle not transparent and cortical cells not visible, rhizomorphs infrequent, emanating hyphae absent. Rhizomorphs, thin (0.25$0.1 \mathrm{~mm}$ ) when originating directly from ectomycorrhizae, at a greater distance thick, up to $2 \mathrm{~mm}$ diam, white near the mycorrhiza and at the base of the fruitbody and nearby, frequently ramified at restricted points, round in cross-section, surface smooth, connection to mantle kind distinct, origin location distal and proximal, joint angle to the mantle $30^{\circ}$, ramification common with an angle of $60^{\circ}$. Sclerotia not observed.

Anatomical characters of mantle in plan views.Mantle plectenchymatous in all layers; all hyphae colorless, clamps lacking. Outer mantle layer (FIG. 1a) with a net of branching hyphae in a regular ring-like arrangement, hyphae 45(8) $\mu \mathrm{m}$ diam, cells $22-23 \mu \mathrm{m}$ long, colorless, matrix not observed, hyphae junctions angle $120^{\circ}$, septa as thick as walls, cells slightly inflated in middle portions, cell wall surface smooth. Middle mantle layer (FIG. 1b) densely plectenchymatous, with distinct hyphal bundles forming ring-like patterns like the outer layers, hyphae colorless, 4-5 $\mu \mathrm{m}$ thick, cells $20 \mu \mathrm{m}$ long, cell walls smooth, anastomoses not observed, matrix lack- 

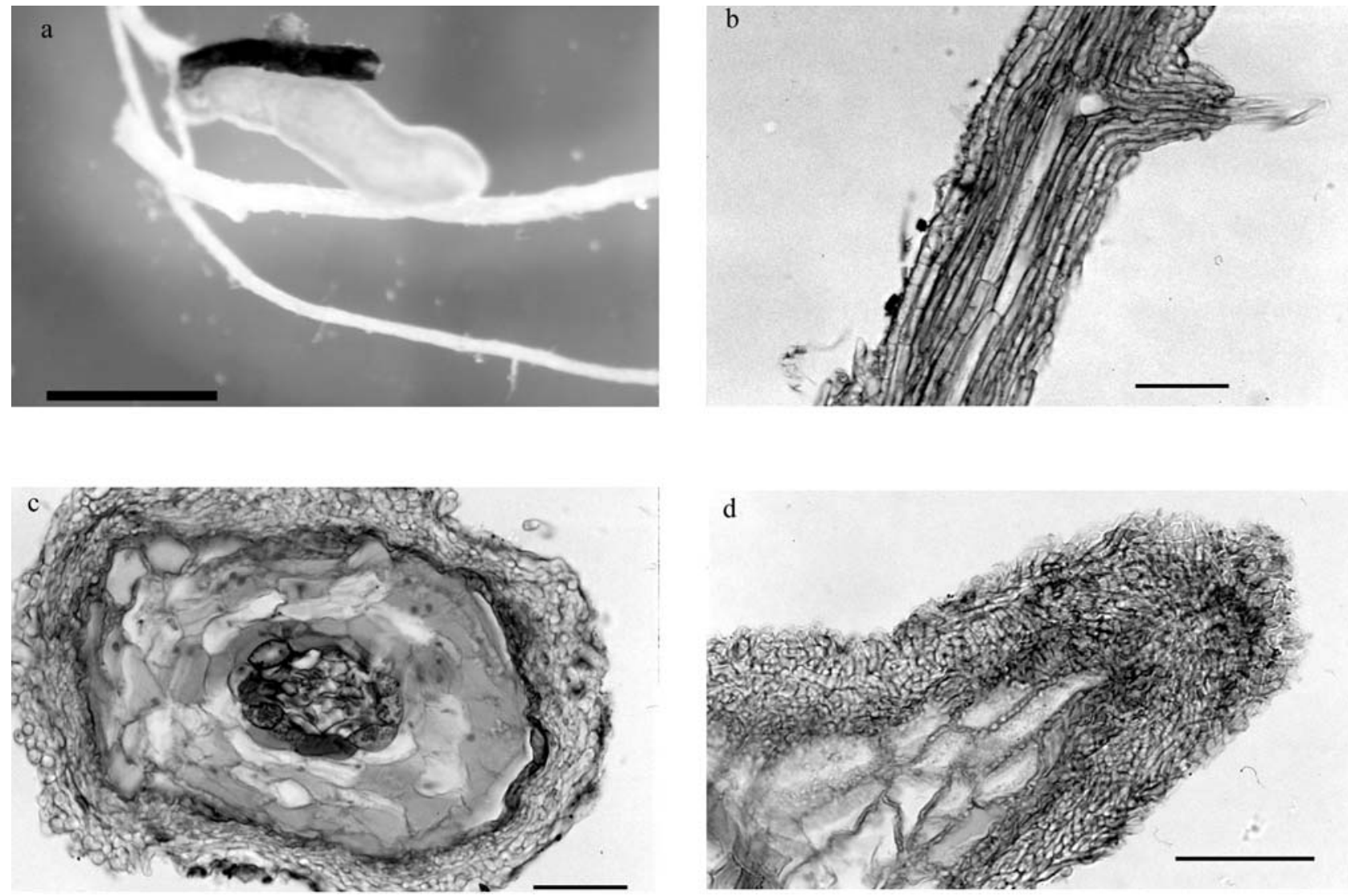

FIG. 2. Anatomical characters of B. edulis ectomycorrhizae. (a) Morphological aspect of an ectomycorrhizae and rhizomorphs. Bar $=1 \mathrm{~mm}$. (b) Longitudinal section of a rhizomorph. Bar $=25 \mu \mathrm{m}$. (c) Cross section of a mycorrhiza. Bar $=$ $25 \mu \mathrm{m}$. (d) Longitudinal section of a mycorrhiza. Bar $=25 \mu \mathrm{m}$.

ing. Inner mantle layer (FIG. 1c) densely plectenchymatous, with broad streaks of parallel hyphae, colorless, 3-5 $\mu \mathrm{m}$ diam, cells 20-22 $\mu \mathrm{m}$ long. Tip with the same structural characteristics as in the older parts of mantle.

Anatomical characters of emanating elements. - Rhizomorphs highly differentiated (type $\mathrm{E}$ according to Agerer 1987-2002), forming internal nodia and nodia at branching points, with hyphae empullate and conical young side-branches, presence of trumpet-like inflated hyphae, $10-11 \mu \mathrm{m}$ thick; central vessel-like hyphae present (FIG. 2b), 7$8 \mu \mathrm{m}$ diam, cells $70-85 \mu \mathrm{m}$ length, $1-1,5 \mu \mathrm{m}$ thick wall, ramification with one side-branch at septum; central nonvessel-like hyphae with septa as thick as the cell walls, $7 \mu \mathrm{m}$ diam, cells $27 \mu \mathrm{m}$ long; peripheral hyphae not specialized, 3-4 $\mu \mathrm{m}$ diam, cells $34 \mu \mathrm{m}$ long, colorless, mostly smooth, but sometimes little granules on the cell wall present, slightly dotted surface, with the hyphae slightly twisted (FIG. 1d) and some vesicles appear in the margin (FIG. 1e) formed by empullated septa of the peripheral hyphae. Clamps lacking. Emanating hyphae lacking. Cystidia lacking. Chlamydospores not observed.

Anatomy of the mantle in longitudinal section.Mantle 18-24 $\mu \mathrm{m}$ thick, 20-22 $\mu \mathrm{m}$ at ectomycorrhizal tip, three different layer discernable (FIG. 2d), all of them plectenchymatous, outer mantle with few calyptra cell remains, hyphae 5$7 \mu \mathrm{m}$ tangential length, 3-4 $\mu \mathrm{m}$ radial diam; middle mantle plectenchymatous, hyphae 7 $8 \mu \mathrm{m}$ tangential length, $2-3 \mu \mathrm{m}$ radial diam; inner mantle plectenchymatous, hyphae $6-7 \mu \mathrm{m}$ tangential length, 3-4 $\mu \mathrm{m}$ radial diam. Tannin cells absent. Cortical cells tangentially oval to elliptic or cylindrical and obliquely oriented, 24-36 $\mu \mathrm{m}$ tangential length, $12-24 \mu \mathrm{m}$ radial diam, CCt $=$ $30 \mu \mathrm{m}, \mathrm{CCq}=18 \mu \mathrm{m}$. Hartig net present in one or in one-half row of cortical cells, adjoining endodermis free of this, hyphal cells around cortical cells beaded, 2-3 $\mu \mathrm{m}$ thick, two hyphal 
rows around cortical cells. Hartig net structure (in plan view) infrequently lobed, lobes without septa, $1.5-2 \mu \mathrm{m}$ width.

Anatomy of mantle in cross-section.-Different layers discernible in the mantle (FIG. 2c). Outer mantle layer plectenchymatous, without calyptra cell remains, hyphae 12-14 $\mu \mathrm{m}$ tangential length, 7$9 \mu \mathrm{m}$ radial diam. Middle mantle layer plectenchymatous, hyphae $13 \mu \mathrm{m}$ tangential length, $4 \mu \mathrm{m}$ radial diam. Inner mantle layer plectenchymatous, hyphae $7 \mu \mathrm{m}$ tangential diam, $4 \mu \mathrm{m}$ radial diam. Cortical cells rectangular, 17-18 $\mu \mathrm{m}$ tangential length, $12-17 \mu \mathrm{m}$ radial diam, CCt $=18 \mu \mathrm{m}, \mathrm{CCq}$ $=15 \mu \mathrm{m}$. Hartig net apparently $1 \frac{1 / 2}{2}$ rows deep, hyphal cells around cortical cells beaded, $2 \mu \mathrm{m}$ thick filling two rows around cortical cells.

Chemical reactions.-Brilliant cresyl blue, dense blue; formol $40 \%$, only the mantle turns graygreenish; Melzer's reagent, dextrinoid; ruthenium red, pink reddish; toluidin blue, dense blue. The rest (acid fuchsin, anilin, etanol $70 \%, \mathrm{FeSO}_{4}$, guaiac, $\mathrm{KOH} 10 \%$, lactic acid, phenole, phenoleanilin, sudan III, sulpho-vanillin and water) absent.

DNA analysis. - Sequences of the nuclear ribosomal DNA fragments were registered in the NCBI GenBank database with these accesion numbers: DQ002921 for the sporocarp sequence, DQ002922 for the mycorrhiza sequence and DQ002923 for the rhizomorph sequence. ITS1/ITS4 amplifications were successful for the sporocarp samples but failed with mycorrhizas and rhizomorphs, which were amplified successfully using the specific ITS1F/BED-4 primers pair. Alignments of the three structures had a $100 \%$ coincidence in the ITS1 region. A search for highly similar sequences by the MegaBLAST procedure was performed to compare our complete sporocarp ITS1, 5.8S and ITS2 sequence with the GenBank ones. A 99-100\% identity with 13 B. edulis entries, 2 B. aestivalis, 2 B. persoonii Bon and $1 B$. venturii Bon was found.

\section{DISCUSSION}

Ectomycorrhiza description and characterization.Characterization of rhizomorph structures seems to be important for distinguishing ectomycorrhizae in the Boletales (Brand 1989). After the revision of the previously published Boletus genus ectomycorrhizae descriptions by Ceruti et al (1983-1984), Ceruti et al (1987-1988), Garrido (1988), Gronbach (1988), Agerer and Gronbach
(1990), Franz and Acker (1995), Hahn (2001), Palfner (2001) and Agerer and Rambold (2004$2005)$ it can be concluded that the ectomycorrhizae of this genus are characterized by the lack of hyphal clamps, the plectenchymatous mantle and rhizomorphs with differentiated hyphae. The mantles of all of the Boletus ectomycorrhizae described are formed by three plectenchymatous layers of colorless hyphae forming ring-like structures (type A, Agerer 1991).

Hahn (2001) described vesicles in the margin of the rhizomorphs formed by $B$. rodoxanthus similar to those described in this study for B. edulis; however, whereas the vesicles of the latter species are smooth, the vesicles of the former species are covered with a dense layer of smooth crystals. Rhizomorphs of $B$. loyo Phillippi and B. putidus E. Horak (Palfner 2001) are similar to the $B$. edulis described here, but both present cystidia. The two descriptions of $B$. aestivalis (Ceruti et al 1983-1984, Garrido 1988) described the characters of the mantle exclusively. All descriptions of B. edulis ectomycorrhizae (Ceruti et al 1987-1988, Gronbach 1988, Garrido 1988, Agerer and Gronbach 1990, Franz and Acker 1995, Palfner 2001, Agerer and Rambold 2004-2005) report smooth hyphae and differentiated rhizomorphs according to Agerer (1999). Although some of the hyphae of the ectomycorrhizae described in this paper are slightly dotted and the external hyphae of the rhizomorphs are slightly twisted, those characteristics could not be considered definitive.

Molecular characterization allowed the identification of the fungal symbiont present in mycorrhizas and rhizomorphs as B. edulis. GenBank sequence comparisons were based mainly on the data provided by Leonardi et al (2005). Although the similarity between the sequence obtained in this work and a few other Boletus species or varieties was also high, all of them belong to the $B$. edulis species complex. Because average nucleotide diversity inside the $B$. edulis species is low compared to other species of the complex (Leonardi 2005), the full coincidence of the fragment amplified from mycorrhizas and rhizomorphs of the sporocarp turned out to be informative for confirming the identity of the fungal partner. On the other hand the lack of success in the PCR amplification from ectomycorrhizas and rhizomorphs when using the universal primers ITS1 and ITS4 indicates that specific primers for PCR amplification can be necessary when working with field, nonaseptic material.

Ecological and practical implications. - B. edulis species complex is associated with a wide range of host trees. B. edulis and B. pinophilus sporocarps 
are found in temperate conifer and broadleaf forests, whereas $B$. aereus and B. aestivalis sporocarps are more termophilic and usually are found in broadleaf and conifer forests (Alessio 1985).

There are few references of mycorrhizal associations of B. edulis with shrubs. Manavella (2004) harvested sporocarps of this species in the Italian Alps, at $2500 \mathrm{~m}$ a.s.l., with presence of Juniperus communis L. subsp. alpina (Suter) Čelak. and Arctostaphylos uva-ursi (L.) Spreng. Both shrubs can form ericoid and vesiculo-arbuscular mycorrhizae, whereas the former also forms ectomycorrhizae (Harley and Harley 1987). Molina and Trappe (1982a) reported members of the Boletales forming arbutoid mycorrhizae with ericaceous shrubs and ectomycorrhizae with coniferous trees.

The extent by which plants benefit from a symbiosis with mycorrhizal fungi varies depending on identity of the plant and the fungus, the physiological state of the plant and environmental conditions (van der Heijden and Sanders 2002). Allen (1991) stated that some plants may form symbiosis with certain fungi depending on the ecological conditions. Molina et al (1992) proposed the concept of ecological specificity that is the influence of biotic and abiotic factors on the ability of plants to form functional mycorrhizae with particular fungi in natural soils. Also Brundrett (2002) suggested that mycorrhizal fungi have a limited capacity for distinguishing the roots of different plant species, so plants primarily would regulate specificity.

Boletus edulis is one of the species that seems to follow this pattern, being able to produce sporocarps in association with unusual host plants such as $C$. ladanifer, a pioneer early stage shrub, when species of Fagales or Pinaceae are absent. This situation would favor the maintenance of soil inoculum reservoria for successional stages. Also the fact that $B$. edulis is able to fruit when associated with 8 y old rockroses may be seen as a dispersion strategy to assure genetic variation (Horton and Bruns 2001).

Studies on wild sporocarp production of edible Boletus have been carried out in different environmental situations (Rondet and Leprince 2001, Martínez 2003, Salerni and Perini 2004). Controlled cultivation and mycorrhizal synthesis studies with Boletus are relatively abundant (Pantidou 1961, 1962, 1964; Tozzi et al 1980, 1981; Molina and Trappe 1982b; Poitou et al 1982; Ceruti et al 1983, 1985; Poitou and Mamoun 1984; Zucherelli 1988, Meotto and Pellegrino 1989). The association with $C$. ladanifer reported in this study, together with the early sporocarp production, offer an alternative economic resource for developing countries and for marginal and inland areas with low incomes. The only attempts to produce edible sporocarps have been done with Helianthemum inoculated with Terfezia (Morte et al 2004). Nursery-controlled inoculations designed to establish short-term production plots could be seen as a feasible and promising way to exploit this peculiar symbiosis.

\section{ACKNOWLEDGMENTS}

We thank Juan Antonio Sánchez Rodríguez (IRMA SL, León, España) for kindly providing the collection of sporocarps, Fernando Palazón Lozano (Huesca, España) for his help in sporocarps identification, Dr Marian Burrell (Universidad de Navarra, Pamplona, España) for her competent assistance with microtome and confocal microscope, and Caren Nordby (Soria, España) and Ana Hernández Fernández de Rojas (DIEF Valonsadero, Soria, España) for their comments on the manuscript. Research by B. Águeda Hernández was financed by Junta de Castilla y León, España.

\section{LITERATURE CITED}

Agerer R, ed. 1987-2002. Colour atlas of ectomycorrhizae. 1st-12th del. Schwäbisch Gmünd, Germany: EinhornVerlag + Druck GmbH.

—_ 1991. Characterization of ectomycorrhiza. In: Norris JR, Read DJ, Varma AK, eds. Techniques for the study of mycorrhiza. London, UK: Academic Press, Methods in Microbiology 23:25-73.

—_ 1999. Anatomical characteristics of identified ectomycorrhizas: an attempt toward a natural classification. In: Varma A, Hock B, eds. Mycorrhiza. 2nd ed. Berlin Heildelberg, Germany: Springer-Verlag. p 633682.

-, Gronbach E. 1990. Boletus edulis. In: Agerer R, ed. Colour atlas of ectomycorrhizae, plate 36. Schwäbisch Gmünd, Germany: Einhorn-Verlag + Druck GmbH.

— Rambold G. 2004-2005. [first posted on 2004-06-01, most recent update 2004-06-05]. DEEMY-an information system for determination and characterization of ectomycorrhizae. Retrieved 2004-06-05 from http:// www.deemy.de

Alessio CL. 1985. Boletus Dill. ex L. (sensu lato). Saronno, Italy: Libreria editrice Biella Giovanna. 712 p.

Allen MF. 1991. The ecology of mycorrhizae. Cambridge, UK: Cambridge University Press. 184 p.

Alonso I, Luis E, Tárrega R. 1992. First phases of regeneration of Cistus laurifolius and Cistus ladanifer after burning and cutting in experimental plots. Int J Wildland Fire 2(1):7-14.

Brand F. 1989. Studies on ectomycorrhiza XXI: beech ectomycorrhizae and rhizomorphs of Xerocomus chrysenteron (Boletales). Nova Hedwigia 48(3-4):469-483.

Brundrett MC. 2002. Coevolution of roots and mycorrhizas of land plants. New Phytologist 154:275-304.

Ceruti A, Ceruti Scurti J, Tozzi M. 1983-1984. Sintesi micorrizica tra Boletus aereus e Quercus pubescens. Allionia 26:5-17.

_, Tozzi M, Reitano G. 1985. Mycorrhizal synthesis 
between Boletus aereus and Castanea sativa. Allionia 27:5-9.

- - - - 1987-1988. Micorrize di sintesi tra Boletus edulis, Pinus sylvestris e Picea excelsa. Allionia 28:117-124.

Demoly JP, Monserrat P. 1993. Cistus. In: Castroviejo Bolivar S, ed. Flora Ibérica. Volúmen III. Madrid, España: Real Jardín Botánico, CSIC. p 319-337.

Díez J. 1998. Micorrizas del bosque mediterráneo: reforestación, biotecnología forestal (micropropagación y micorrización in vitro) y ecología molecular [Doctoral dissertation]. España, Alcalá de Henares: Univ. de Alcalá. 242 p.

Fontana A, Giovannetti G. 1978-1979. Simbiosi micorrizica fra Cistus incanus L. ssp. incanus e Tuber melanosporum Vitt. Allionia 23:5-11.

Franz F, Acker G. 1995. Rhizomorphs of Picea abies ectomycorrhizae: ultrastructural aspects and elemental analysis (EELS and ESI) on hyphal inclusions. Nova Hedwigia 60(1-2):253-267.

Fusconi A. 1983. The development of the fungal sheath on Cistus incanus short roots. Can J Bot 61:2546-2553.

Gardes M, Bruns TD. 1993. ITS primers with enhanced specificity for basidiomycetes-application to the identification of mycorrhizae and rusts. Mol Ecol 2:113-118.

Garrido N. 1988. Agaricales s.l. und ihre mycorrhizen in den nothofagus-wäldern Mittelchiles. Berlin-Stuttgart, Germany: J. Cramer: Bibliothec Mycol 120. 528 p.

Gronbach E. 1988. Charakterisierung und identifisierung von ektomykorrhizen in einem fichtenbestand mit untersuchungen zur merkmalsvariabilität in sauer beregneten flächen. Berlin-Stuttgart, Germany: J. Cramer: Bibliothec Mycol 125. 217 p.

Hahn C. 2001. Boletus rodoxanthus Kallenb. + Cistus cf. ladanifer L. In: Agerer R, Danielson RM, Egli S, Ingleby K, Luoma D, Treu R, eds. Descriptions of ectomycorrhizae. Vol. 5. Schwäbisch Gmünd, Germany: EihornVerlag. p 15-22.

Hall IR, Lyon AJE, Wang Y, Sinclair L. 1998. Ectomycorrhizal fungi with edible fruiting bodies. 2. Boletus edulis. Econ Bot 52:44-56.

Hall TA. 1999. BioEdit: a user-friendly biological sequence alignment editor and analysis program for Windows 95/98/NT. Nucleic Acids Symposium Series 41:95-98.

Harley JL, Harley EL. 1987. A check-list of mycorrhiza in the British flora. New Phytol 105(suppl.):1-102.

Horton TR, Bruns TD. 2001. The molecular revolution in ectomycorrhizal ecology: peeking into the black-box. Mol Ecol 10:1855-1871.

Leonardi M, Paolocci F, Rubini A, Simonini G, Pacioni G. 2005. Assessment of inter- and intraspecific variability in the main species of Boletus edulis complex by ITS analysis. FEMS Microbiol Let 243:411-416.

Llamas B, Terrón A. 2003. Atlas fotográfico de los hongos de la Península Ibérica. León, España: Celarayn Editorial. 547 p.

Manavella M. 2004. Funghi d'alta quota in valle Po Boletus edulis Bull.: Fr. (e non solo!) in zona alpina. Il Micologo 17(110):3-19.

Martínez F. 2003. Producción y aprovechamiento de Boletus edulis Bull.: Fr. en un bosque de Pinus sylvestris L. Bases para la ordenación y valoración económica del recurso micológico forestal. Serie técnica, Consejería de Medio Ambiente, Junta de Castilla y León. Madrid, Spain: Egraf, S.A. 134 p.

Meotto F, Pellegrino S. 1989. Comportamento in campo di querce e castagni micorrizati con Boletus edulis Bull. L'Informatore Agrario 47:57-63.

Molina R, Trappe JM. 1982a. Lack of mycorrhizal specificity by the ericaceous hosts Arbutus menziesii and Arctostaphyllos uva-ursi. New Phytol 90:495-509.

— $-1982 \mathrm{~b}$. Patterns of ectomycorrhizal host specificity and potential among Pacific Northwest conifers and fungi. For Sci 28:423-458.

—, Massicotte H, Trappe JM. 1992. Specificity phenomena in mycorrhizal symbioses: community-ecological consequences and practical implications. In: Allen MF, ed. Mycorrhizal functioning, an integrative plantfungal process. New York, US: Chapman \& Hall. p 537-423.

Moor D, Brodmann P, Nicholas G, Eugster A. 2002. Polymerase chain reaction (PCR) for the detection of king bolete (Boletus edulis) and slippery jack (Suillus luteus) in food samples. Eur Food Res Technol 214:340-345.

Moreno G. 1977. Nouveaux taxons de la famille Boletaceae Chev. trouvés en Espagne. Doc Mycol 7(27-28):1-19.

Moreno Arroyo B, Jiménez F, Gómez J, Infante F. 1996. Setas de Andalucía. Sevilla, España: Centro Andaluz del Libro. 390 p.

Morte A, Gutiérrez G, Honrubia M. 2004. Desert truffle cultivation: a rehabilitation tool for degraded semiarid lands. In: Faz A, Ortiz R, García G, eds. Abstract Book of the 4th International Conference on Land Degradation. $426 \mathrm{p}$.

Muñoz F, Navarro C, eds. 1993. Cistaceae. In: , Castroviejo Bolivar S, ed. Flora Ibérica. Volúmen III. Madrid, España: Real Jardín Botánico, CSIC. p 318-436.

Nuytinck J, Verbeken A, Rinaldi AC, Leonardi M, Pacioni M, Comandini O. 2004. Characterization of Lactarius tesquorum ectomycorrhizae on Cistus sp. and molecular phylogeny of related European Lactarius taxa. Mycologia 96(2):272-282.

Oria de Rueda JA, Díez J. 2002. Guía de árboles y arbustos de Castilla y León. Palencia, España: Ediciones Cálamo. 381 p.

Palfner G. 2001. Taxonomische studien an ektomykorrhizen aus den nothofagus-wäldern Mittelsüdchiles. Berlin-Stuttgart, Germany: J. Cramer: Bibliothec Mycol 190. 243 p.

Pando F. 2000. Bases de datos en linea de las colecciones de criptógamas del Herbario MA. Retrieved 2005-3-4 from http://www.rjb.csic.es/herbario/crypto/crydbe.htm

Pantidou ME. 1961. Cultural studies of Boletaceae: Gyrodon merulioides and four species of Boletinus. Can J Bot 39:1149.

1962. Cultural studies of Boletaceae: carpophores of Phlebopus lignicola in culture. Can J Bot 40:1313.

-__ 1964. Carpophores of Xerocomus badius and Xerocomus illudens in culture. Can J Bot 42:1147. 
Poitou N, Mamoun M, Delmas J. 1982. Quelques résultats obtenus concernant la mycorhization de plantes hôtes par les champignons mycorhiziens comestibles. In: Les mycorhizes. Colloques de l'INRA 13:295301.

1984. Mycorhization contrôlée de Pinus uncinata dans les Pyrénées. Acta Biol Mont 4:115125 .

Rondet J, Leprince F. 2001. Les cahiers du cèpe. 1. Les bases de la production. Conseil Régional Midi-Pyrénées, INRA, Lycée Agricole et Forestier de Vic-enBigorre. Vic-en-Bigorre, France, 85 p.

Salerni E, Perini C. 2004. Experimental study for increasing productivity of Boletus edulis s.l. in Italy. Forest Ecology and Management 201:161-170.

Sánchez Rodríguez JA, Flórez Serrano J, Sierra Fernández JL, Guerra Burton B, Chamorro Suárez M. 2004. Los hongos: manual y guía didáctica de micología. León, España: IRMA SL. 734 p.

Singer R. 1986. The Agaricales in modern taxonomy. 4th ed. Koenigstein, Germany: Koeltz Scientific Books. $981 \mathrm{p}$.

Smith SE, Read DJ. 1997. Mycorrhizal Symbiosis. 2nd ed. London, UK: Academic Press Lim. 605 p.

Torres P, Roldán A, Lansac AR, Martin A. 1995. Ectomycor- rhizal formation between Cistus ladanifer and Laccaria laccata. Nova Hedwigia 60:311-315.

Tozzi M, Ceruti J, Berta G. 1980-81. Preliminary researches of synthesis between Boletus edulis and Quercus pubescens. Allionia 24:5-11.

van der Heijden MGA, Sanders IR. 2002. Mycorrhizal ecology: synthesis and perspectives. In: van der Heijden MGA, Sanders IR, eds. Mycorrhizal ecology. Berlin Heildelberg, Germany: Springer-Verlag, Ecological Studies 157:441-456.

Verlhac A, Giraud M, Leteinturier J. 1990. La truffe guide pratique. Paris, France: CTIFL. 108 p.

Wenkart S, Roth-Bejerano N, Mills D, Kagan-Zur V. 2001. Mycorrhizal associations between Tuber melanosporum mycelia and transformed roots of Cistus incanus. Plant Cell Report 20:369-373.

White TJ, Bruns T, Lee S, Taylor J. 1990. Amplification and direct sequencing of fungal ribosomal RNA genes for phylogenetics. In: Innis MA, Gelfand DH, Sninsky JJ, White TJ, eds. PCR protocols. A guide to methods and applications. San Diego, USA: Academic Press. p 315-322.

Zucherelli G. 1988. Prime esperenze sulla produzione di piante forestali micorrizate con Boletus edulis. Monti e Boschi 39:11-14. 